\title{
Using HPLC-DAD and GC-MS Analysis Isolation and Identification of Anticandida Compounds from Gui Zhen Cao Herbs (Genus Bidens): An Important Chinese Medicinal Formulation
}

\author{
Kulsoom Zahara ${ }^{1}$, Yamin Bibi ${ }^{1}$, Saadia Masood ${ }^{2}$, Sobia Nisa ${ }^{3}$ (D), Abdul Qayyum ${ }^{4, *(D)}$, Muhammad Ishaque ${ }^{1}$, \\ Khurram Shahzad ${ }^{5}{ }^{(D}$, Waseem Ahmed ${ }^{6}$, Zahid Hussain Shah ${ }^{7}$, Hameed Alsamadany ${ }^{8} \mathbb{D}$, Seung-Hwan Yang ${ }^{9} \mathbb{D}$ \\ and Gyuhwa Chung ${ }^{9, *(D)}$
}

check for

updates

Citation: Zahara, K.; Bibi, Y.;

Masood, S.; Nisa, S.; Qayyum, A.;

Ishaque, M.; Shahzad, K.; Ahmed, W.;

Shah, Z.H.; Alsamadany, H.; et al.

Using HPLC-DAD and GC-MS

Analysis Isolation and Identification

of Anticandida Compounds from Gui

Zhen Cao Herbs (Genus Bidens): An

Important Chinese Medicinal

Formulation. Molecules 2021, 26, 5820

https://doi.org/10.3390/

molecules 26195820

Academic Editors: Mohamed El-Amir

F. Hegazy, Paul W. Pare and

Mahmoud A. A. Ibrahim

Received: 13 August 2021

Accepted: 21 September 2021

Published: 25 September 2021

Publisher's Note: MDPI stays neutral with regard to jurisdictional claims in published maps and institutional affiliations.

Copyright: (c) 2021 by the authors. Licensee MDPI, Basel, Switzerland. This article is an open access article distributed under the terms and conditions of the Creative Commons Attribution (CC BY) license (https:// creativecommons.org/licenses/by/ $4.0 /)$.
1 Department of Botany, PMAS-Arid Agriculture University Rawalpindi, Rawalpindi 46300, Pakistan; kulsoomzahara@gmail.com (K.Z.); dryaminbibi@uaar.edu.pk (Y.B.); mishaque270@gmail.com (M.I.)

2 Department of Statistics \& Mathematics, PMAS-Arid Agriculture University Rawalpindi, Rawalpindi 46300, Pakistan; saadia.masood@uaar.edu.pk

3 Department of Microbiology, The University of Haripur, Haripur 22620, Pakistan; sobia@uoh.edu.pk

4 Department of Agronomy, The University of Haripur, Haripur 22620, Pakistan

5 Department of Plant Breeding and Genetics, The University of Haripur, Haripur 22620, Pakistan; kshahzad@uoh.edu.pk

6 Department of Horticulture, The University of Haripur, Haripur 22620, Pakistan; dr.waseemahmed@uoh.edu.pk

7 Department of Plant Breeding and Genetics, PMAS Arid Agriculture University, Rawalpindi 46300, Pakistan; shahzahid578@hotmail.com

8 Department of Biological Sciences, King Abdul Aziz University, Jeddah 21589, Saudi Arabia; halsamadani@kau.edu.sa

9 Department of Biotechnology, Chonnam National University, Gwangju 59626, Korea; ymichigan@chonnam.ac.kr

* Correspondence: aqayyum@uoh.edu.pk (A.Q.); chung@chonnam.ac.kr (G.C.)

Abstract: Gui Zhen Cao is an herbal formulation that has been documented in Chinese traditional medicine as a remedy for diarrhea, dysentery, inflammation, and toxicity. The sources of this formulation (Bidens pilosa L., Bidens biternata (Lour.) Merr. \& Sherff, Bidens bipinnata L.) are also listed in ethnomedicinal reports all over the world. In this study, all these plants are tested for in vitro anticandida activity. A quantitative evaluation of the phytochemicals in all these plants indicated that their vegetative parts are rich in tannins, saponins, oxalates, cyanogenic glycoside and lipids; moreover, the roots have high percentages of alkaloids, flavonoids, and phenols. The results indicated significant anticandida activity, especially for the hexane extract of B. bipinnata leaves which inhibited C. albicans $(42.54 \%)$, C. glabrata $(46.98 \%)$, C. tropicalis $(50.89 \%)$, C. krusei $(40.56 \%)$, and C. orthopsilosis (50.24\%). The extract was subjected to silica gel chromatography and 220 fractions were obtained. Purification by High Performance Liquid Chromatography with DiodeArray Detection (HPLC-DAD) and Gas Chromatography tandem Mass Spectrometry (GC-MS/MS) analysis led to the identification of two anticandida compounds: dehydroabietic and linoleic acid having an inhibition of 85 and $92 \%$, respectively.

Keywords: Gui Zhen Cao; traditional Chinese medicine; linoleic acid; Bidens bipinnata

\section{Introduction}

Since prehistoric times, human beings have used plants as a source of medicine; in fact, they were the only source of medicine until the arrival of iatrochemistry in the 16th century [1]. After that, there was a massive shift from natural to synthetic medicine; today, modern Western medicine is based on synthetic compounds. However, in several parts of 
world, natural medicinal systems-Ayurveda, Unani Tib and Traditional Chinese Medicine (TCM)-also exist [2].

Gui Zhen Cao is a traditional Chinese herb that is described as having detoxifying properties. The Oriental Materia Medica says that it clears blood stagnation and wind dampness [3]. In the book Thousand Formulas and Thousand Herbs of Traditional Chinese Medicine, it is reported to remove heat from the gastrointestinal tract and cure diarrhea, dysentery, and stomach ache of the heat type (Table 1). Wind-heat is a type of common cold in Chinese medical language. Sore throat, feeling warm and/or agitated (whether or not there is a fever), yellow or green-colored phlegm, and aversion to heat are some indications of wind-heat. It is also accompanied with Heat cramps and Damp Wind, both responsible for muscles fatigue.Heat cramps is a painful, brief muscle cramps that occur during excessive work in a hot environment. Whereas Damp Wind has effects similar to those of the common cold, with sore limbs, listlessness, nausea, anorexia, and diarrhea and can cause diseases like arthritis.

Table 1. Evidence of Gui Zhen Cao medicinal potential In Chinese Traditional medicine.

\begin{tabular}{|c|c|c|}
\hline Book Name & $\begin{array}{l}\text { Targets of Gui Zhen Cao } \\
\text { Curative Properties }\end{array}$ & Reference \\
\hline Oriental Meteria Medica & $\begin{array}{l}\text { Wind-dampness, dispersing stagnant } \\
\text { blood, and invigorating blood. }\end{array}$ & [3] \\
\hline Handbook of Chinese Medicinal Herbs & $\begin{array}{l}\text { Dysentery, laryngalgia, dysphagia, } \\
\text { vomiting, cardiac spasm and } \\
\text { esophageal dilatation. }\end{array}$ & [4] \\
\hline Prescriptions Worth A Thousand Gold & Blended with pig fat to cure finger cuts. & - \\
\hline $\begin{array}{l}\text { Chinese-English Manual of } \\
\text { Common-Used Herbs }\end{array}$ & $\begin{array}{c}\text { Common cold of the wind-heat type, } \\
\text { influenza; clear away heat and toxic } \\
\text { materials: sore throat, appendicitis, snake } \\
\text { bite, and centipede bite. }\end{array}$ & [5] \\
\hline $\begin{array}{c}\text { Thousand Formulas and Thousand Herbs } \\
\text { of Traditional Chinese Medicine }\end{array}$ & $\begin{array}{l}\text { Heat from gastro-intestinal tract: for } \\
\text { diarrhea, dysentery and stomach ache of } \\
\text { heat type. }\end{array}$ & [6] \\
\hline
\end{tabular}

In the Chinese-English Manual of Common-Used Herbs, this formulation is said to cure the common cold, sore throat, appendicitis, centipede bite and snake bite, and prevent influenza [5]. The sources of Gui Zhen Cao are three herbs: i.e., Bidens pilosa L., Bidens biternata (Lour.) Merr. \& Sherff, Bidens bipinnata L. [5]. In the manual under Gui Zhen Cao, these plants are all widely reported to be used for treating different ailments all around the world (Table 2).

Various ethnobotanical reports also indicated the use of these plants for skin and vaginal infections [7-10]. Studies also reported that these plants enhanced macrophage activity against candida infection in mice [11]. The use of Bidens spp. for vaginitis is also documented in the literature. For example, Borges et al. [12] reported the use of its fresh juice.

Previously, the anticandida activity of $B$. pilosa was reported $[11,13]$ but not the effects of $B$. bipinnata or B. biternata. Therefore, we conducted a quantitative phytochemical analysis of the reproductive and vegetative parts of Gui Zhen Cao herbs to identify the active anticandidal phytochemicals. 
Table 2. Ethnomedicinal uses of Gui Zhen Cao herbs.

\begin{tabular}{|c|c|c|c|}
\hline Disease & Plant Used & Mode of Application & Reference \\
\hline \multirow{2}{*}{ Stomach ache } & B. pilosa & Decoction of fresh leaves & [14] \\
\hline & B. bipinnata & Not stated & [15] \\
\hline \multirow{2}{*}{ Diarrhea } & B. pilosa & Decoction and fresh leaves & [16] \\
\hline & B. bipinnata & Not stated & [17] \\
\hline \multirow{2}{*}{ Anti-inflammatory } & B. pilosa & Not stated & [18] \\
\hline & B. biternata & Poultice of leaf & [19] \\
\hline \multirow{3}{*}{ Dysentery } & B. pilosa & Decoction of whole plant & [20] \\
\hline & B. biternata & Not stated & [21] \\
\hline & B. bipinnata & Not stated & [17] \\
\hline \multirow{2}{*}{ Headache } & B. pilosa & Decoction of whole plant & [22] \\
\hline & B. biternata & Bruised leaves on forehead & [23] \\
\hline \multirow{2}{*}{ Colds } & B. pilosa & Fresh leaves or decoction of whole plant & {$[24]$} \\
\hline & B. biternata & Decoction of whole plant & [25] \\
\hline \multirow{2}{*}{ Eye Infection } & B. pilosa & Juice of fresh leaves used as eye and ear drops & [26] \\
\hline & B. biternata & Same as above & [27] \\
\hline \multirow{2}{*}{ Wounds } & B. pilosa & Crushed herb & [28] \\
\hline & B. biternata & Leaves rubbed as a hemostatic & [29] \\
\hline \multirow{2}{*}{ Snake bite } & B. pilosa & Pulverized herb & {$[30]$} \\
\hline & B. biternata & Fresh roots paste is given as a drink & [19] \\
\hline Toothache & B. biternata & Roots are chewed & {$[21]$} \\
\hline \multirow{2}{*}{ Cough } & B. pilosa & Decoction of whole plant is taken orally & [31] \\
\hline & B. biternata & Infusion is given & [27] \\
\hline Stomach ulcers & B. pilosa & Maceration or juice; taken orally & [32] \\
\hline Tuberculosis & B. biternata & Decoction or maceration; taken orally & [29] \\
\hline \multirow{2}{*}{ Vaginitis } & B. pilosa & Decoction of fresh leaves are applied & [12] \\
\hline & B. bipinnata, B. pilosa & Not stated & [33] \\
\hline Candidiasis & Bidens biternata & Essential oil & [34] \\
\hline \multirow{2}{*}{ Skin infections } & B. pilosa & Ground leaves & [35] \\
\hline & B. bipinnata & Not stated & [17] \\
\hline
\end{tabular}

\section{Results}

The quantitative determination of phytochemicals in B. pilosa, B. biternata and B. bipinnata is presented in Table 3. This study indicated that vegetative parts (leaves, stems, and roots) are higher in tannins, oxalates, cyanogenic glycoside, and lipids; however, alkaloids, flavonoids and phenols were higher in the reproductive parts (flowers and achenes). Alkaloids were the highest in B. biternata $(0.499 \mathrm{mg} / 100 \mathrm{~g})$ compared to the other species. B. biternata was also found to have a higher tannin content $(1090 \mathrm{mg} / 100 \mathrm{~g})$ followed by B. pilosa $(1030 \mathrm{mg} / 100 \mathrm{~g}$. The amount of saponins was the highest in $B$. bipinnata. A higher phenol content was also observed in vegetative and reproductive parts of all Bidens species B. bipinnata $(4.04,5.98)$, B. pilosa $(3.58,4.98)$ and B. biternata $(3.14,4.09)$. 
Table 3. Quantity of Phytochemicals found in Bidens species.

\begin{tabular}{|c|c|c|c|c|c|c|c|c|c|}
\hline \multicolumn{2}{|c|}{ Plant Sample } & \multirow{2}{*}{$\begin{array}{c}\begin{array}{c}\text { Tannin } \\
(\mathbf{m g} / \mathbf{1 0 0} \mathbf{g})\end{array} \\
1090 \pm 1.4142\end{array}$} & \multirow{2}{*}{$\begin{array}{c}\begin{array}{c}\text { Alkaloid } \\
(\%)\end{array} \\
0.499\end{array}$} & \multirow{2}{*}{$\begin{array}{c}\begin{array}{c}\text { Flavonoid } \\
(\%)\end{array} \\
6.9\end{array}$} & \multirow{2}{*}{$\begin{array}{c}\begin{array}{c}\text { Saponins } \\
(\%)\end{array} \\
3.6\end{array}$} & \multirow{2}{*}{$\begin{array}{c}\begin{array}{c}\text { Oxalate } \\
(\%)\end{array} \\
2.21\end{array}$} & \multirow{2}{*}{$\begin{array}{c}\begin{array}{c}\text { Cyanogenic } \\
\text { Glycoside } \\
\text { (mg/100 g) }\end{array} \\
620 \pm 0.836\end{array}$} & \multirow{2}{*}{$\begin{array}{c}\begin{array}{c}\text { Phenols } \\
\text { (mg/g) }\end{array} \\
3.14 \pm 0.5468\end{array}$} & \multirow{2}{*}{$\begin{array}{c}\begin{array}{c}\text { Lipid } \\
(\mathbf{\%})\end{array} \\
8.6\end{array}$} \\
\hline Pidons hitomnata & Vegetative parts & & & & & & & & \\
\hline Dineris vilernata & Reproductive parts & $956 \pm 2.8280$ & 0.234 & 9.2 & 6.6 & 2.08 & $501 \pm 1.927$ & $4.09 \pm 0.5463$ & 2.8 \\
\hline \multirow{2}{*}{ Bidens bipinnata } & Vegetative parts & $930 \pm 4.7140$ & 0.231 & 5.09 & 7.09 & 2.97 & $520 \pm 0.275$ & $4.04 \pm 1.6750$ & 6.4 \\
\hline & Reproductive parts & $865 \pm 0.9428$ & 0.201 & 8.2 & 9.8 & 1.76 & $465 \pm 1.3568$ & $5.98 \pm 0.7979$ & 5.76 \\
\hline \multirow{2}{*}{ Bidens pilosa } & Vegetative parts & $1030 \pm 0.9436$ & 0.357 & 6.98 & 8.32 & 3.05 & $500 \pm 0.6571$ & $3.58 \pm 0.1454$ & 7.2 \\
\hline & Reproductive parts & $827 \pm 0.9428$ & 0.214 & 7.6 & 9.8 & 2.09 & $487 \pm 0.2468$ & $4.98 \pm 0.7564$ & 6.54 \\
\hline
\end{tabular}

Candidiasis is a type of infection that mostly occurs in the mouth, throat, and vagina. It sometime effect organs like the kidney. In this study, three species of the genus Bidens (B. pilosa, B. bipinnata and B. biternata) were evaluated for their anticandida properties (Figure 1). The hexane extract of B. bipinnata appeared to be the most active with percentage inhibition of 63.09 (C. albicans), 60.68 (C. glabrata), 58.66 (C. tropicalis), 60.67 (C. krusei) and 67.40 (C. orthopsilosis) (Figure 2). The hexane extract of different parts of B. bipinnata (leaves, stem, root, flower and achene's) were again tested for anticandida activity. The leaves' hexane extract appeared to be the most active (Figure 3). Thus, for large scale extraction, the hexane extract of the leaves was selected. From $200 \mathrm{~g}$ of leaf powder in $1000 \mathrm{~mL}$ hexane, $15 \mathrm{~g}$ of extract was obtained and run into a silica column. The extract was further separated into 220 fractions by silica gel chromatography.

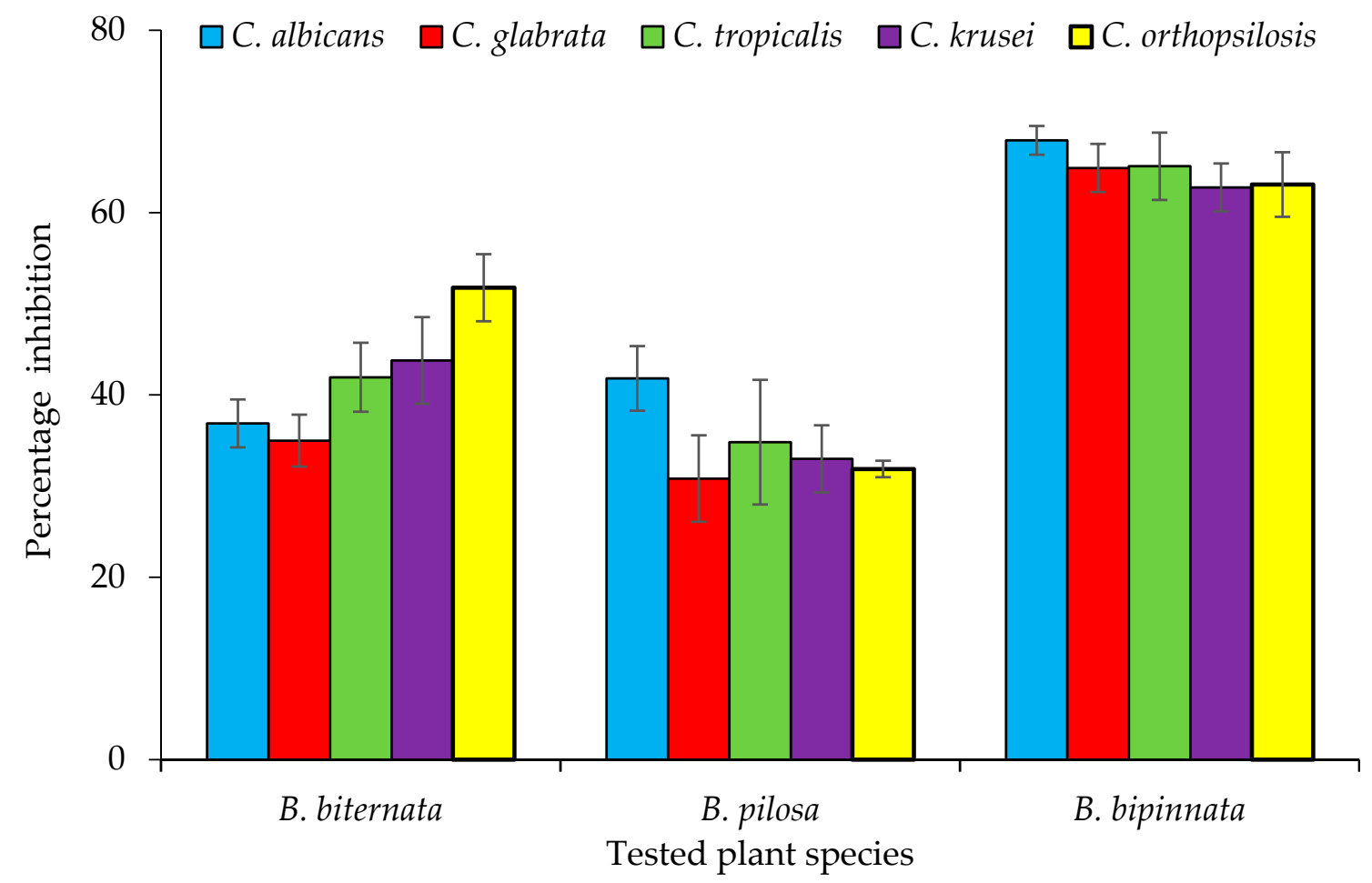

Figure 1. Anticandida activity of Bidens bipinnata, Bidens pilosa and Bidens biternata. 


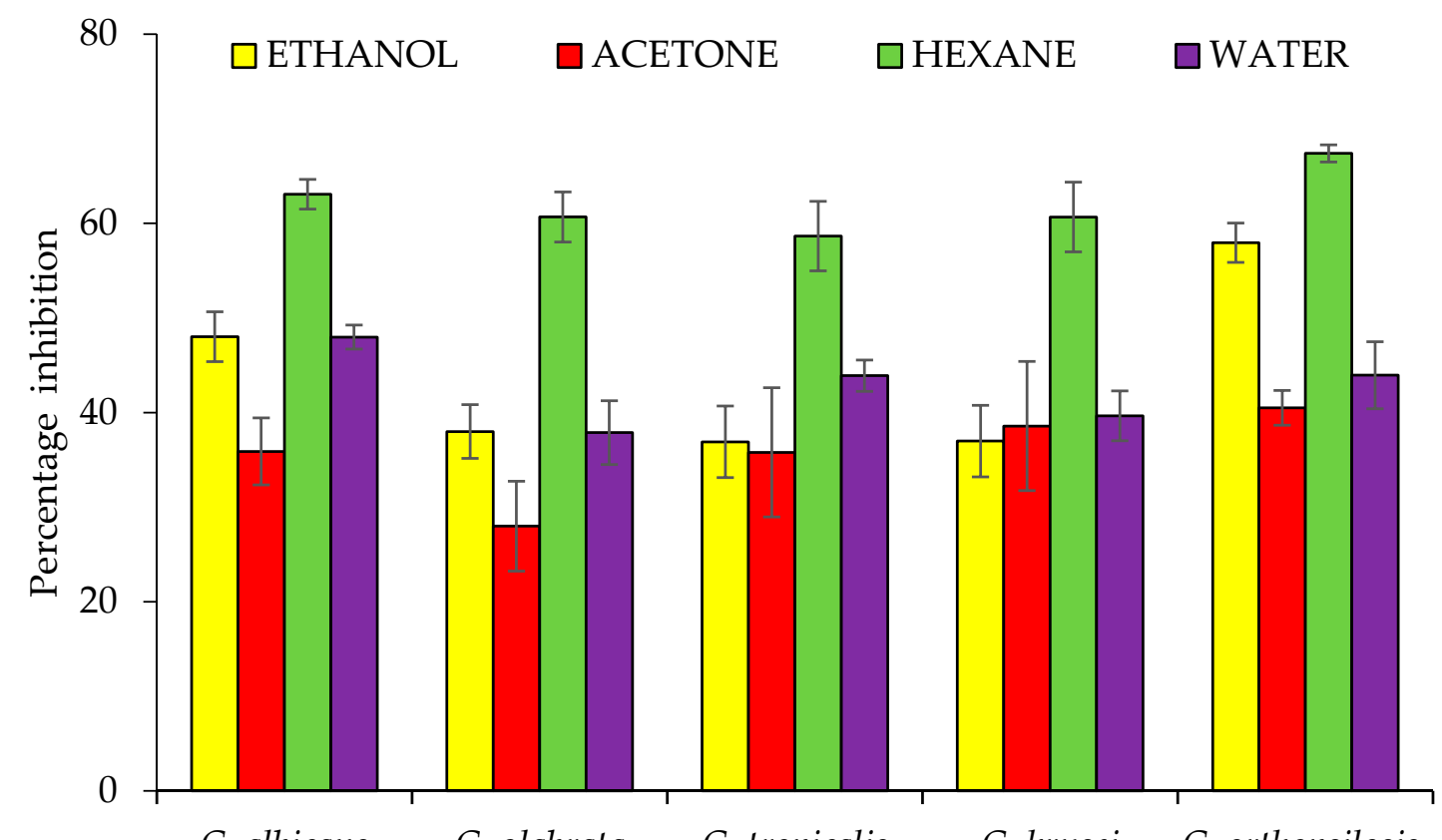
C. albicans
C. glabrata
C. tropicalis
C. krusei
C. orthopsilosis Tested candida strains

Figure 2. Anticandida activity of different extracts of Bidens bipinnata; positive control fluconazole.

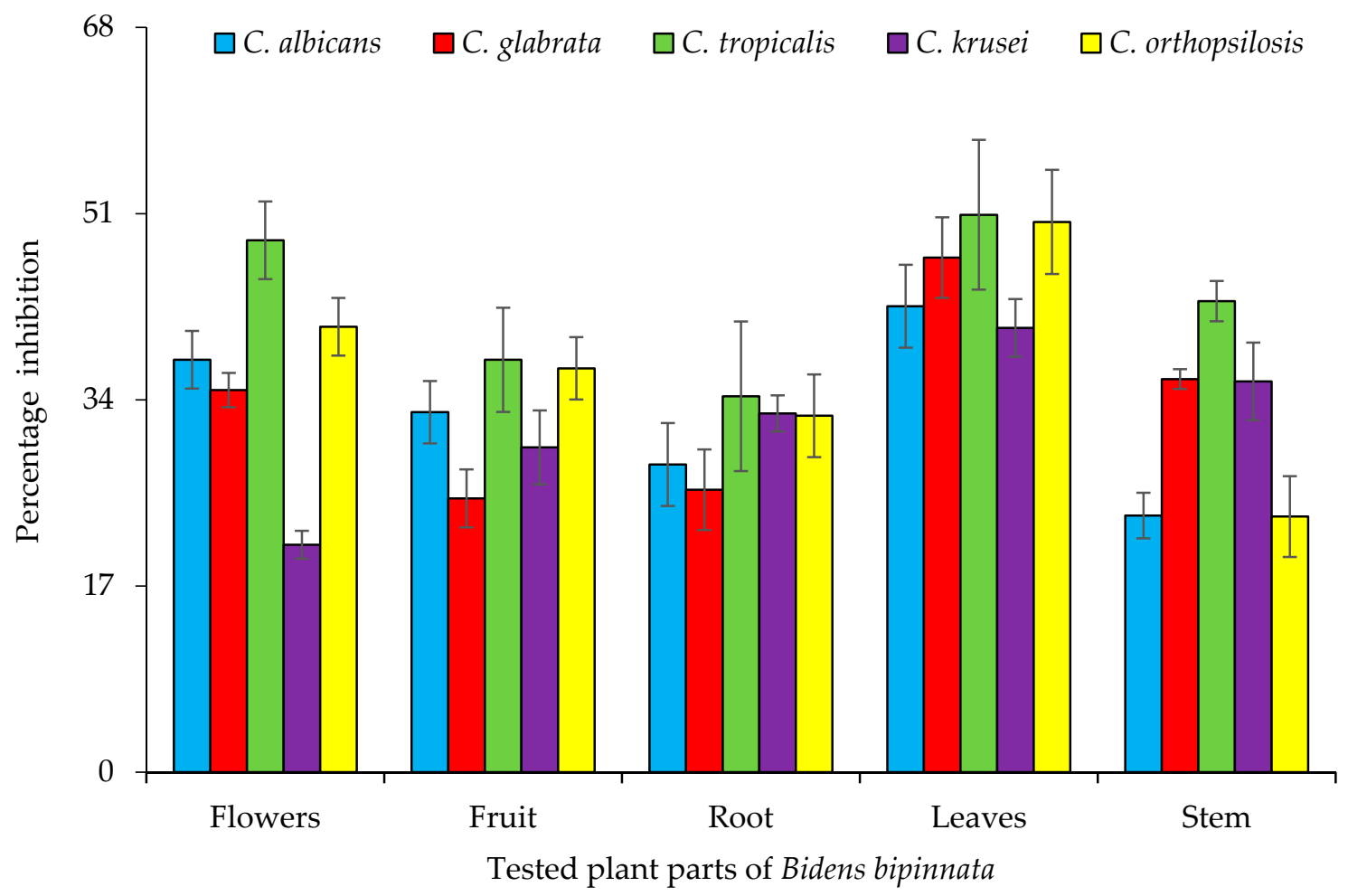

Figure 3. Anticandida activity of Hexane extract of different parts of Bidens bipinnata.

The fractions obtained from the silica column were tested against $C$. albicans and activity was observed in fractions 25-29 and 89-92. All active fractions were dried, weighted and again tested for anticandida activity using a serial dilution protocol and persistent activity was observed in fraction 25-29, indicating the presence of active anticandida compounds (Figure 4). Fraction 27 was further separated using HPLC-DAD Analysis with water: acetonitrile mobile phase (starting at $15 \%$ acetonitrile for $5 \mathrm{~min}$ and linearly increasing to 
$100 \%$ over $35 \mathrm{~min}$ ). The chromatogram recorded well-resolved peaks at $254 \mathrm{~nm}$ (Figure 5).

All 60 one-minute fractions were collected and re-tested for anticandida activity.
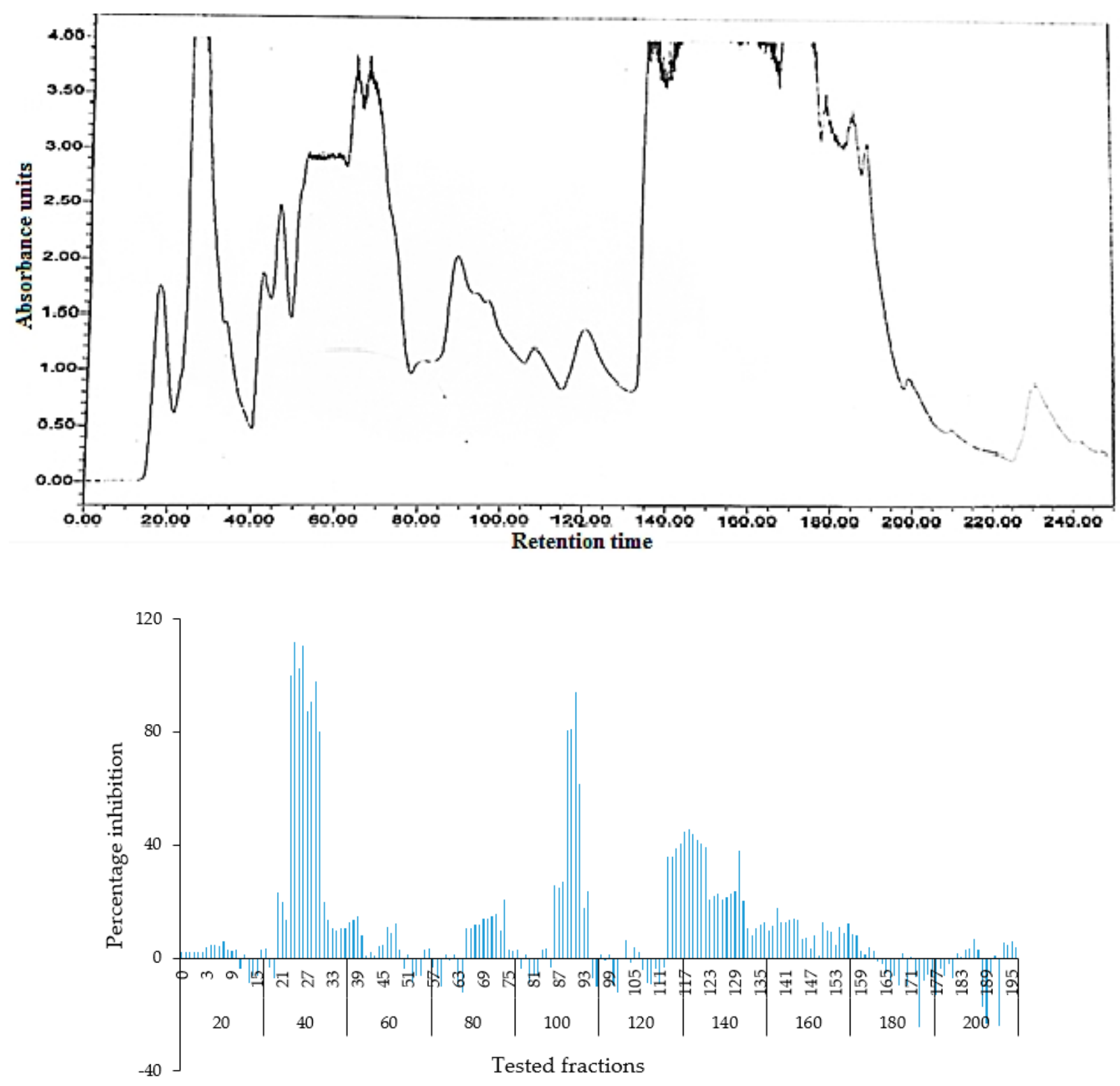

Figure 4. Top panel: Overlaid chromatogram of from a silica gel column of the hexane extract of Bidens bipinnata leaves; fractions were collected per minute and tested for activity (percentage inhibition of C. albicans) (bottom panel). 

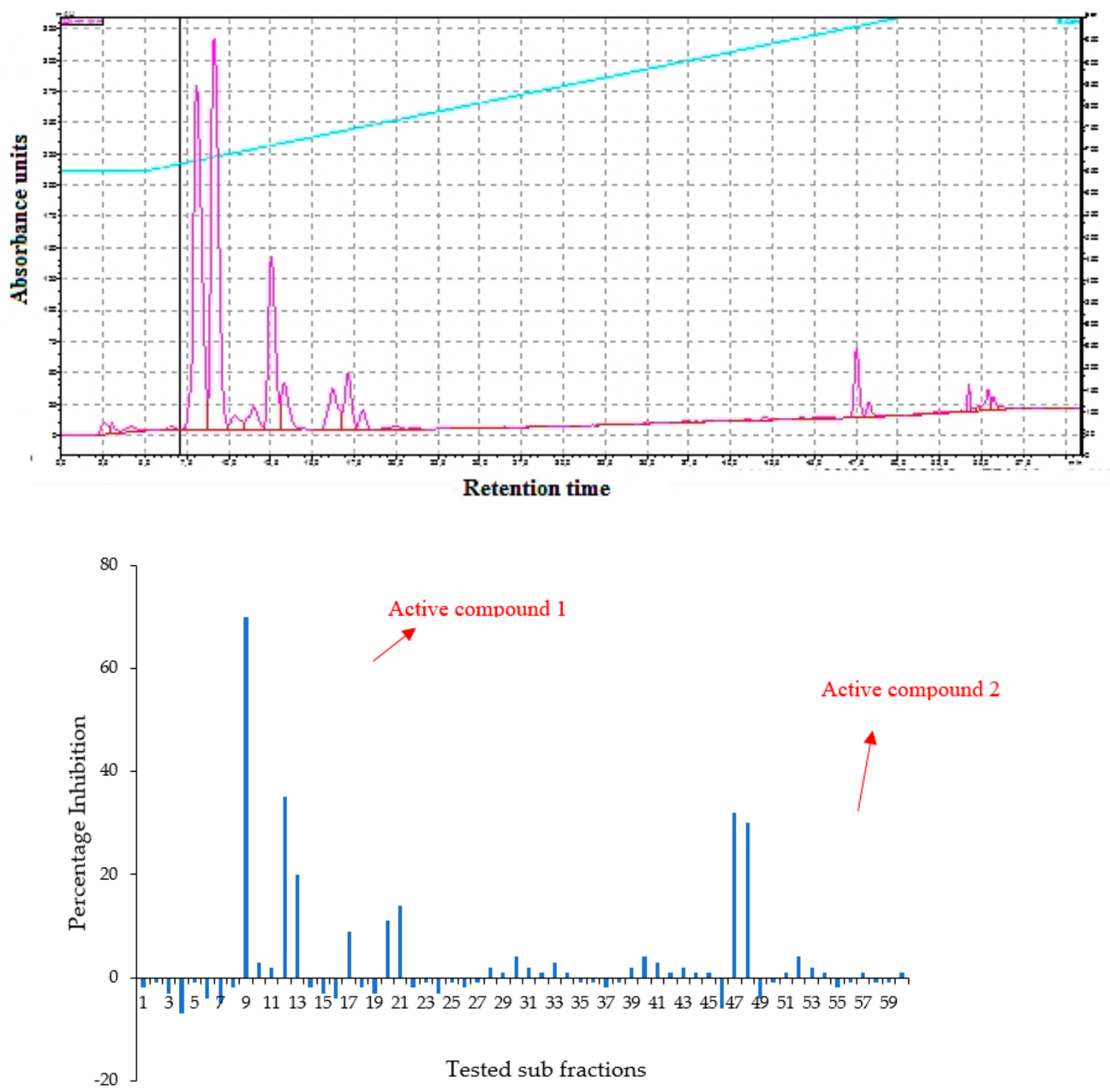

Figure 5. Top panel: HPLC chromatogram of fraction 49 of silica gel column; fractions were collected per minute and tested for activity (percentage inhibition of C. albicans) (bottom panel).

The purity of the active peaks was tested using TLC and purified active peaks were subjected to UV Vis Spectrophotometry and GCMS for identification (Figures 6 and 7). Compound 1 was identified as dehydroabietic acid with a purity and yield of 94.52 and $54.93 \%$, respectively; compound 2 was identified as linoleic acid with a purity and yield of 92.12 and $65.81 \%$, respectively, (Figure 8). The anticandida activity of both compounds was quantified using a microdilution test on C. albicans: linoleic acid had a stronger activity with inhibition of $92 \%$ compared to $85 \%$ for dehydroabietic acid. 
(a)

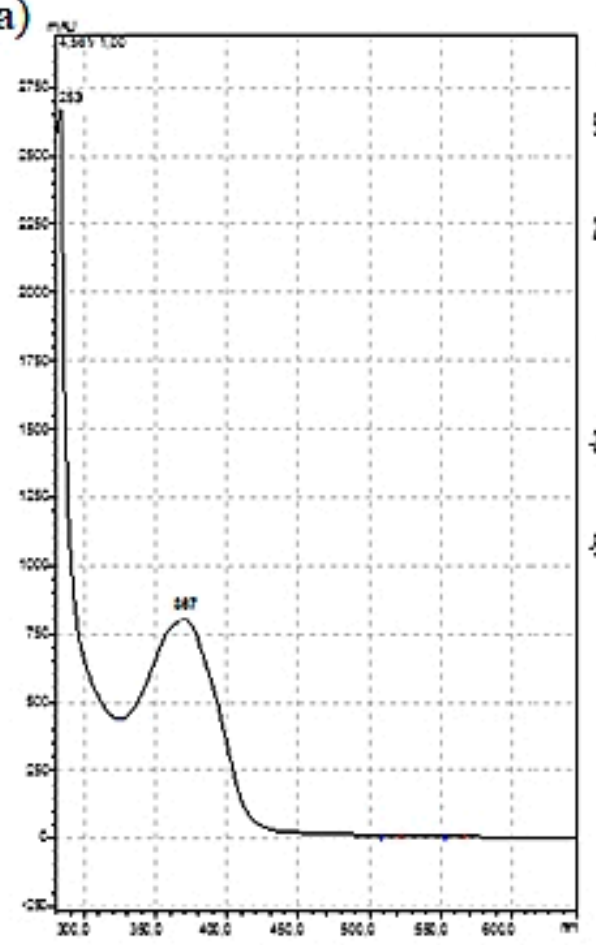

(b)

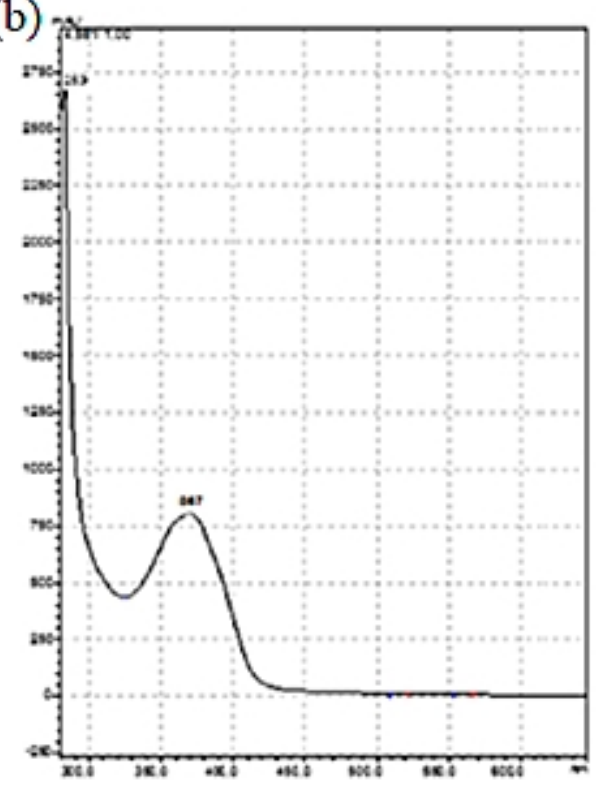

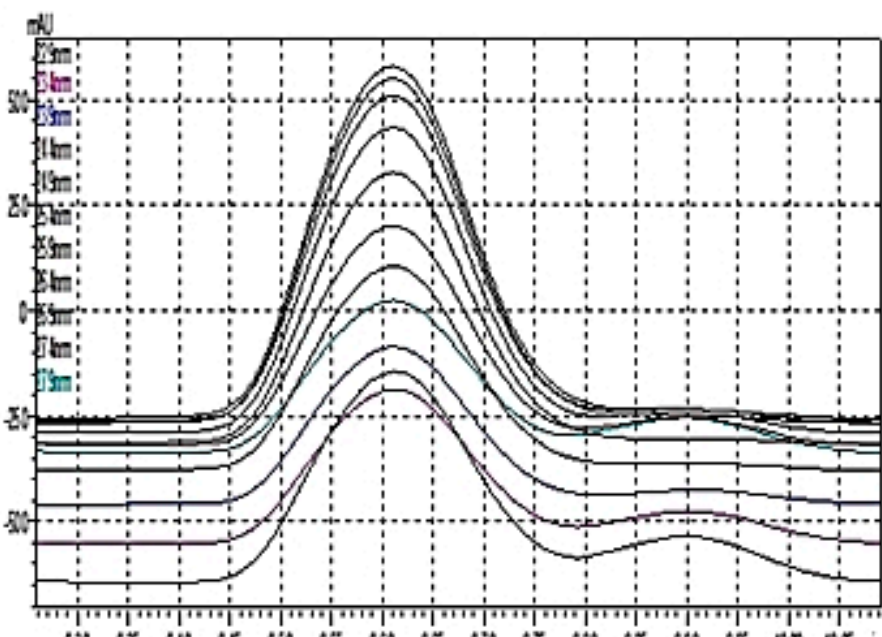

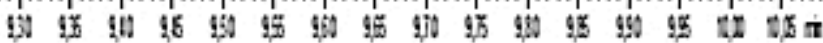

Detected at: $8.89 \mathrm{~min}$

Peak purity index : 0.963957

Single point threshold: 1.000000

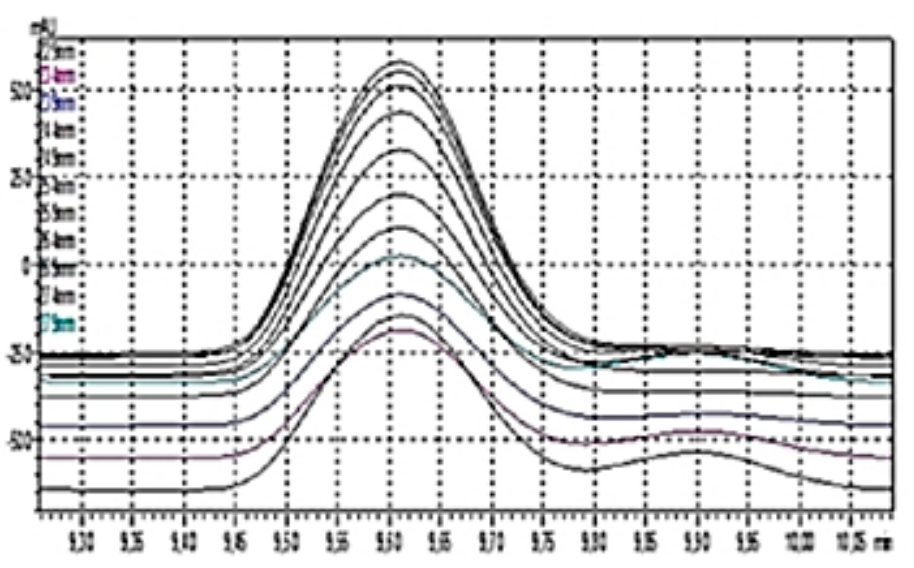

Detected at: $47 \mathrm{~min}$

Peak purity index: 0.963957

Single point threshold: 1.000000

Figure 6. UV-vis apex absorption spectra of (a) Compound 1 (Dehydroabietic acid); and (b) Compound 2 (Linoleic acid). 
(a)
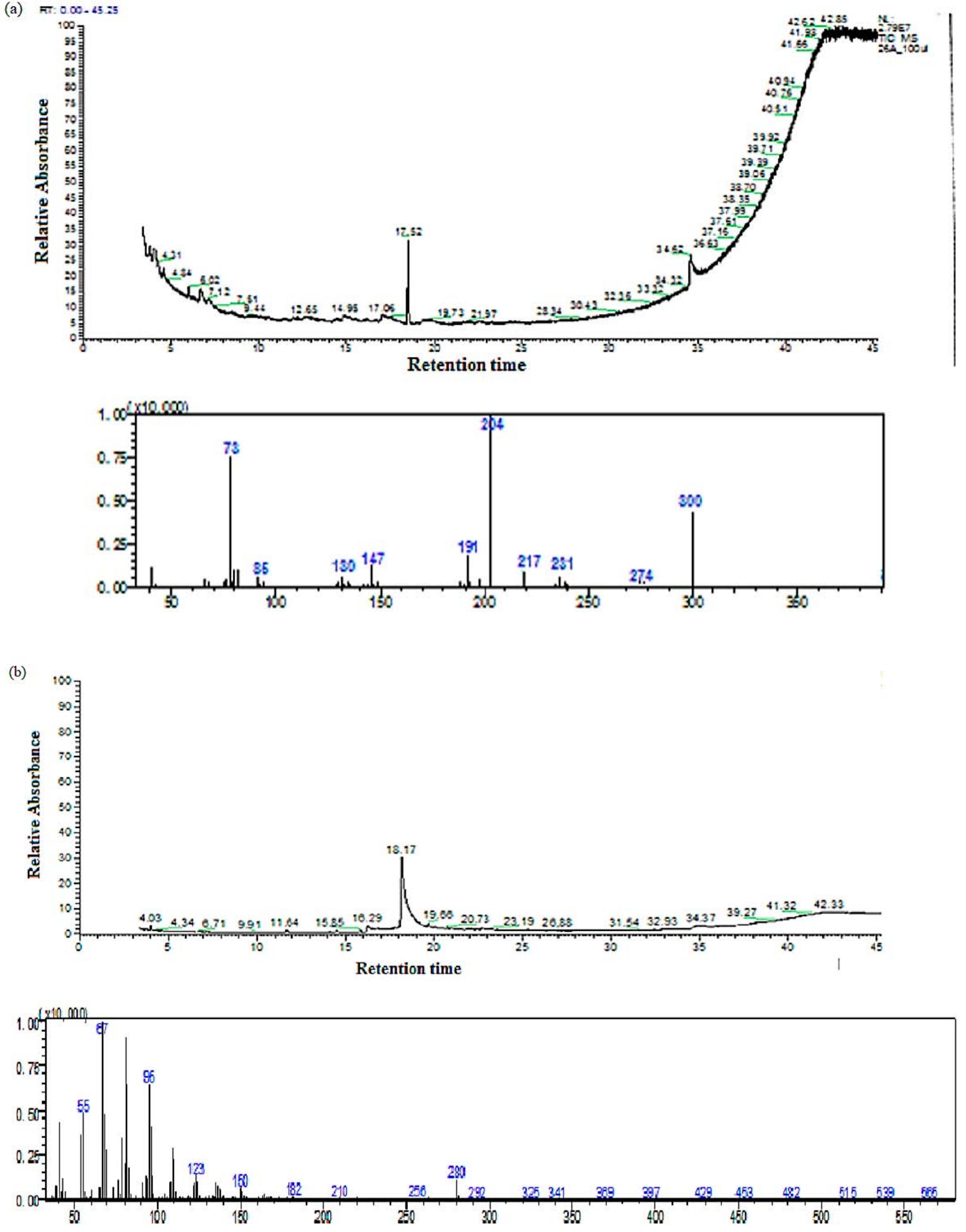

Figure 7. Mass spectra of (a) Compound 1 (Dehydroabietic acid) and (b) Compound 2 (Linoleic acid). 


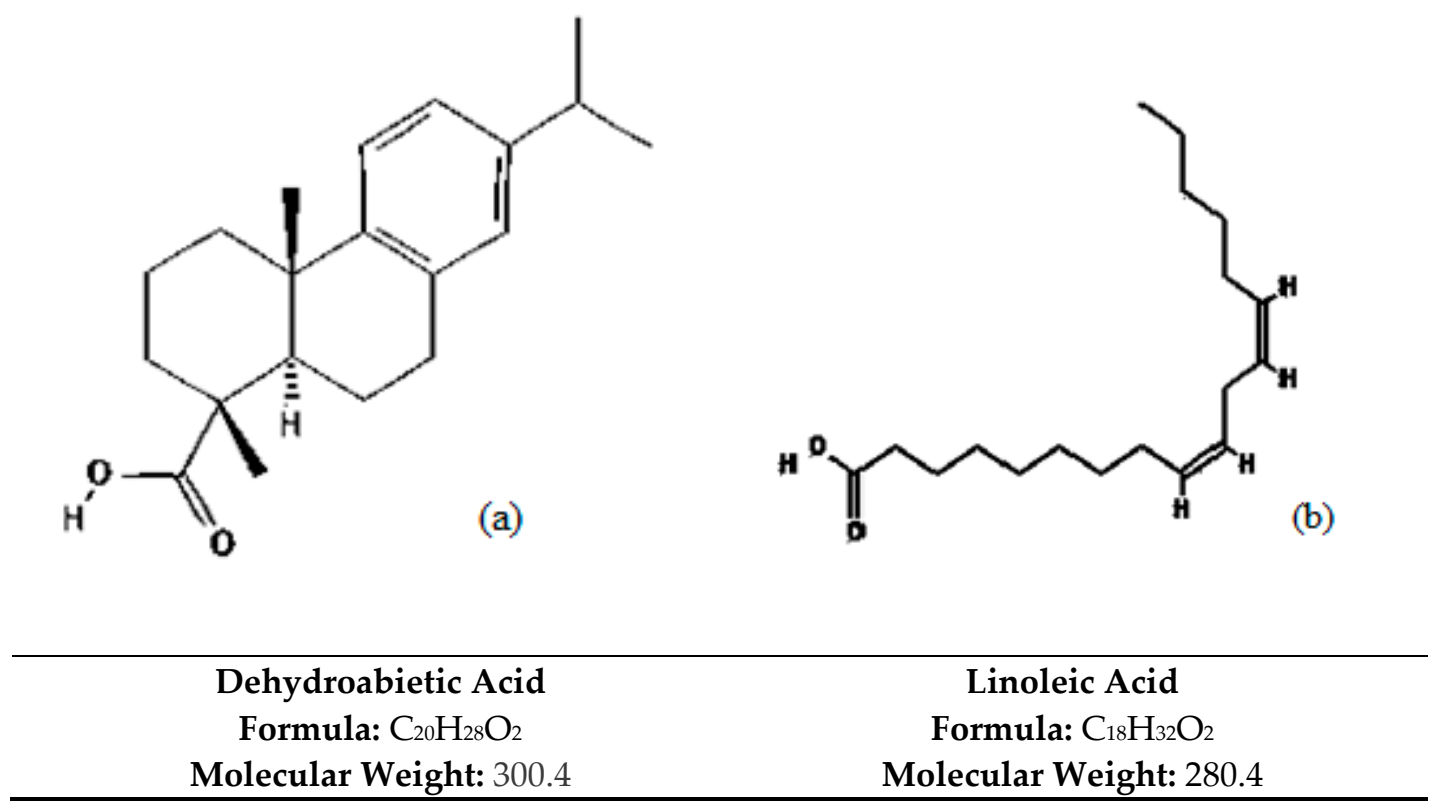

Figure 8. (a) Compound 1 (Dehydroabietic acid) and (b) Compound $\mathbf{2}$ (Linoleic acid). Compounds $\mathbf{1}$ and $\mathbf{2}$ in the most active peaks were analysed by mass spectrometry.

\section{Discussion}

Traditional Chinese Medicine is one of the most common medicinal systems, and various formulations documented in its literature led to the development of modern drugs. In this study, Gui Zhen Cao was evaluated for its pharmacological potential. All three of its plant sources (B. biternata, B. pilosa, and B. bipinnata) were analyzed. These plants showed the presence of phytochemicals, especially tannins, phenols, and alkaloids. Borges et al. [36] indicated that there is a strong correlation between their phenolic content and antioxidant potential. In addition, tannins and alkaloids are thought to be responsible for antimicrobial activity.

During in vitro evaluation it was observed that the hexane extract of B. bipinnata appeared to have a notable inhibitory effect against all candida species. Thus, high anticandida activity might be due to the high level of phenols and saponins [36]. In Handbook of Chinese Medicinal Herbs, a decoction of Gui Zhen Cao is said to be effective against diarrhea, and since candida species are often considered to be a cause of diarrhea, our results validate its traditional use.

Using bioassay guided fractionation, this study led to the isolation of two anticandida compounds, the most active of which, linoleic acid, was isolated from B. bipinnata. The mass spectrum of this compound showed a molecular ion peak at $\mathrm{m} / z 280.4$ corresponding to the molecular formula $\mathrm{C}_{18} \mathrm{H}_{32} \mathrm{O}_{2}$. Linoleic acid is a colorless or white polyunsaturated omega- 6 fatty acid that is soluble in many organic solvents but nearly insoluble in water. Fatty acids are very important for disease prevention, and linoleic acid can prevent a variety of inflammatory, depressive, cardiovascular, and certain disturbed neurological diseases [37]. It is also reported to decrease serum cholesterol and increase membrane fluidity [38].

The compound had been previously identified from Asteraceae members i.e., Achillea biebersteinii Afan [39], Centaurea vlachorum [40] and Achillea gypsicola [41]. From the genus Bidens (Bidens pilosa [42] and B. odorata), linoleic acid was previously isolated. From $B$. bipinnata there is only one report of its ameliorative effects [43].

In our study, a high anticandida activity of linoleic acid isolated from B. bipinnata was reported. Previously linoleic acid was widely reported to have antimicrobial properties. It inhibited the growth of Gram-positive bacterial species with MIC varying between 0.01 
and $1.0 \mathrm{mg} / \mathrm{mL}$ [37]. In the case of fungal strains it successfully inhibited the growth of the pathogenic fungi Rhizoctonia solani, Pythium ultimum, Pyrenophora avenae and Crinipellis perniciosa [44]. Greenway and Dyke [45] reported the inhibitory effect of linoleic acid on the growth of Staphylococcus aureus, probably by increasing the permeability of the bacterial membrane as a result of its surfactant action. Another study conducted on the effect of linolenic acid against Helicobacter pylori suggest that linoleic acid caused structural changes in the microbial cell membrane, thereby distressing its integrity and causing the seepage of cytoplasmic contents [46].

The second-most active compound isolated was dehydroabietic acid with a molecular ion peak at $m / z 300$, corresponding to molecular formula $\mathrm{C}_{20} \mathrm{H}_{28} \mathrm{O}_{2}$. It is a pyran-2,4-dione substituted at position 3 by an acetyl group and at position 6 by a methyl group. It is classified as a pyrone derivative. Pyrones are class of heterocyclic compounds that contain an unsaturated six-membered ring containing a ketone functional group and one oxygen atom. A variety of pyrones were previously isolated from plants: Gentiana pedicellata [47], Hyptis pectinate [48], Piper methysticum [49], Ravensara anisate [50] and Alpinia zerumbet [51].

Dehydroabietic acid was previously isolated from a variety of plant species: Abies balsamea (L.) Mill [52], Pinus elliottii [53], Pinus densiflora [54], Nicotiana tabacum and Catharanthus roseus [55]. From Asteraceae members, it was identified from Commiphora opobalsamum [56], Solidago altissima [57], and Egletes viscosa [58]. However, there was no report of this compound from genus Bidens.

Dehydroabietic acid is a chief representative of aromatic abietanes. Similar to diterpenoids, these abietans are typically recognized as chemical defense agents. Antiviral, antileishmanial, antifungal, cytotoxic, antitumor, antiulcer, anti-plasmodial, cardiovascular, antimicrobial, antioxidant and anti-inflammatory properties are the biological activities of this group described up to now [59]. Numerous studied have reported the antimicrobial activity of dehydroabietic acid. Franich et al. [60] noticed antifungal activity of its derivatives against Dothistroma pini. Feio et al. [61] confirmed that dehydroabietic acid restricted the growth of Trametes versicolor $(\mathrm{EC} 50=0.04)$.

In this study, dehydroabietic acid also revealed substantial anticandida activity: $85 \%$. Previous studies indicated its antimicrobial effect $[52,54,62]$ and suggested that dehydroabietic acid may cause a reduction in cell size disrupt cell membranes and cell walls. They also indicated that it decreased the proton gradient in microbial cells [55,56]. This occurrence is related with the disturbance of proton transport in the membrane-bound ATPase, causing uncoupling of the oxidative phosphorylation [63].

\section{Materials and Methods}

\subsection{Standard and Reagents}

Solvents (Ethyl acetate, hexane, acetone, methanol, acetonitrile) of High-Performance Liquid Chromatography(HPLC)-grade purity from Sigma-Aldrich Co. (St. Louis, MO 63118, United States) deionized sterile water (Milli-Q Reagent Water System, St. Louis, MO, USA), YPD (yeast extract peptone dextrose) agar medium (Lab M Ltd., Lancashire, UK) and DMSO from Sigma-Aldrich (St. Louis, MO, United States) were used.

\subsection{Collection and Identification of Plants}

B. pilosa, B. biternata, B. bipinnata, was collected from Azad, Jammu and Kashmir, Pakistan, during spring 2017 to spring 2018 (Figure 9). All parts of these plants (root, stem, leaves, flowers and achene's) were collected in sterile polyethylene bags labeled with the location, name and date of collection. Plant specimens were identified by a taxonomist, and voucher specimens were deposited in the herbarium of Quaid-i-Azam University, Islamabad, Pakistan, for future reference. All parts were thoroughly washed, and diseased or unwanted plant parts were removed. All plant parts were dried at ambient temperature and shade dried to maintain their volatile oils, if present. The plants were fully desiccated to prevent microbial growth and ground into a fine powder, which was kept in in Pearl Pet plastic jars. 

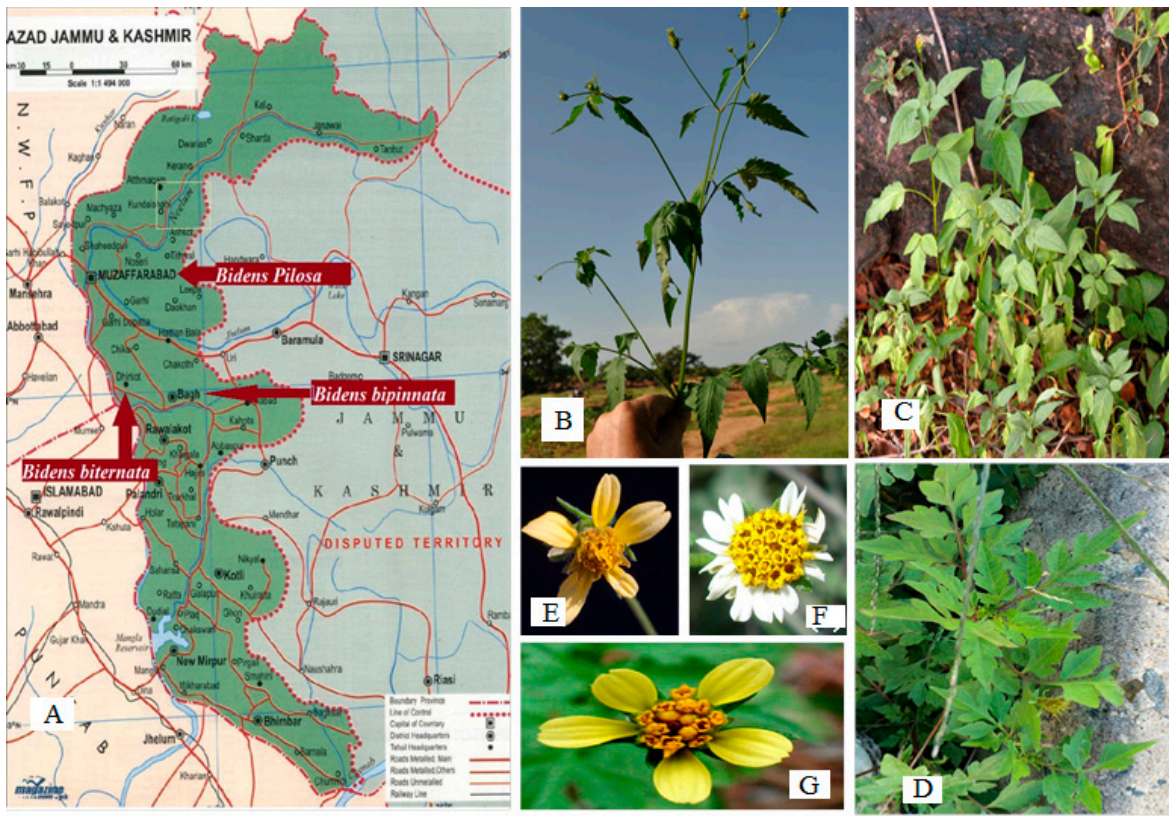

Figure 9. (A): Collection areas of Plants; (B): Bidens biternata; (C): Bidens Pilosa; (D): Bidens bipinnata; (E): Bidens biternata flower; (F): Bidens pilosa flower; (G): Bidens bipinnata flower.

\subsection{Quantitative Analysis of Phytochemicals}

\subsubsection{Phenolics}

By using the Folin-Ciocalteu colorimetric method, total phenolics were determined [64]. Plant extracts were dissolved in methanol, and a $1000 \mu \mathrm{g} / \mathrm{mL}$ solution was prepared. As a standard, Gallic acid was used. Each test solution $(300 \mu \mathrm{L})$ was taken in a vial and after five minutes, $2.25 \mathrm{~mL}$ of Folin-Ciocalteu phenol reagent from Sigma-Aldrich (St. Louis, MO 63118, United States) was added. This mixture was placed in ambient temperature for $90 \mathrm{~min}$ and absorbance was taken afterword. Total phenolics were presented as mg Gallic acid equivalent (GAE) per gram.

\subsubsection{Tannins}

The plant powder was mixed with distilled water (1:2), shaken and filtered. A reagent was prepared by mixing ferric chloride $(0.1 \mathrm{~N})$ and ferro-cyanide $(0.008 \mathrm{~mol})$ and added to the filtrate, after which absorbance was measured [64].

\subsubsection{Alkaloids}

Alkaloids were measured using the protocol given by Okumu et al. [65]. The plant powder was mixed with acetic acid, mixed filtered and reduced. Ammonium hydroxide was added, and the precipitates, when formed, were collected, washed, and dried. After that, their weight was measured.

\subsubsection{Terpenoids}

The plant powder was put into a beaker with $9 \mathrm{~mL}$ of ethanol and allowed to stand for $24 \mathrm{~h}$, after which it was filtered, and the filtrate was placed in a separating funnel and $10 \mathrm{~mL}$ of petroleum ether was added. The ether extract was then placed in a glass vial and allowed to dry [66]. Once the ether evaporated, the terpenoids were estimated by the following formula:

$$
\% \text { Terpenoids }=\text { Weight } \text { of Tannins } / \text { Weight } \text { of Extract } \times 100
$$




\subsubsection{Saponins}

Using the protocol reported by Ejikeme et al. [64], the plant powder $(5 \mathrm{~g})$ was mixed with $20 \%$ aqueous ethanol $\left(100 \mathrm{~cm}^{3}\right)$ and heated at $55^{\circ} \mathrm{C}$ for $4 \mathrm{~h}$ in a conical flask in a water bath. The residue was again treated as in the previous step. In a separate funnel, the extract was again treated with $20 \mathrm{~cm}^{3}$ of diethyl ether and shaken. Once layer formation occurred, the ether layer was discarded, and the aqueous layer was collected. The procedure was repeated with of $n$-butanol $\left(60 \mathrm{~cm}^{3}\right)$ and $5 \%$ sodium chloride $\left(10 \mathrm{~cm}^{3}\right)$. The $n$-butanol layer was collected and heated in a water bath until dried. The Saponins were calculated as;

$$
\% \text { Saponins }=\text { Weight of Saponins } / \text { Weight of Extract } \times 100
$$

\subsubsection{Oxalates}

Oxalates were determined by using the method proposed by Ejikeme et al. [64]. A $2.50 \mathrm{~g}$ plant sample was extracted with $0.3 \mathrm{M} \mathrm{HCl}\left(20 \mathrm{~cm}^{3}\right)$ three times at $50{ }^{\circ} \mathrm{C}$ and constantly stirred for $1 \mathrm{~h}$. The extract was treated with $5 \mathrm{M}$ ammonium hydroxide $\left(1.0 \mathrm{~cm}^{3}\right)$, 3 drops glacial acetic acid, 2 drops phenolphthalein, and $5 \%$ calcium chloride $\left(1.0 \mathrm{~cm}^{3}\right)$. The solution was allowed to stand for $3 \mathrm{~h}$ and was centrifuged for $15 \mathrm{~min}$ at $3000 \mathrm{rpm}$. Precipitates were collected and washed with hot water three times. In the tube, $3 \mathrm{M}$ tetraoxosulphate acid $\left(2.0 \mathrm{~cm}^{3}\right)$ was added, and precipitates were dissolved by warming in a $70{ }^{\circ} \mathrm{C}$ water bath. The solution was titrated by $0.01 \mathrm{M}$ potassium permanganate until it turned pink. The solution was left to stand until it again became colorless, after which it was warmed at $70{ }^{\circ} \mathrm{C}$ for $3 \mathrm{~min}$ and again titrated until the pink colour reappeared and remained for at least $30 \mathrm{~s}$. The oxalates were calculated as;

$$
\mathrm{C}_{2} \mathrm{O}^{2-}{ }_{4}+8 \mathrm{H}^{+}+\mathrm{MnO}^{2-}{ }_{4}=2 \mathrm{CO}_{2}+4 \mathrm{H}_{2} \mathrm{O}+\mathrm{Mn}^{2+}
$$

Ratio of reacting ions $=1: 1 ;$ From $\mathrm{M}_{1} \mathrm{~V}_{1}=\mathrm{M}_{2} \mathrm{~V}_{2} ; \mathrm{M}_{1}$ was the molarity of the $\mathrm{KMnO}_{4}$; $\mathrm{V}_{1}$ was the volume of $\mathrm{KMnO}_{4} ; \mathrm{M}_{2}$ was the molarity of the extract; $\mathrm{V}_{2}$ was volume of the extract; Molecular weight of $\mathrm{CaCO}_{3}=100$; Weight of oxalate in titre $=M_{2} \times$ molecular weight $=X g$; Weight of oxalate in titrant $2 \mathrm{~cm}^{3}=(X / 100) \times 2=Y ; 100 \mathrm{~cm}^{3}$ of oxalate extract $=(\mathrm{Y} / 2.5) \times 100 \mathrm{~g}=\mathrm{W}$

$$
\% \text { Oxalate composition } \mathrm{g} / 100 \mathrm{~g}=(\mathrm{W} / 2.5) \times(100 / 1)
$$

\subsubsection{Cyanogenic Glycoside}

In dry wood powder $(1 \mathrm{~g})$, distilled water $\left(200 \mathrm{~cm}^{3}\right)$ was added and allowed to stand for $2 \mathrm{~h}$. In a conical flask, full distillation was done with $20 \mathrm{~cm}^{3}$ of $2.5 \% \mathrm{NaOH}$, and tannic acid was used as an antifoaming agent. Ammonium hydroxide $6 \mathrm{M}\left(8 \mathrm{~cm}^{3}\right)$ tested extract $\left(100 \mathrm{~cm}^{3}\right)$ and $5 \%$ potassium iodide was added. The mixture was then titrated with $\mathrm{AgNO}_{3}$ $(0.02 \mathrm{M})$. The end point was considered when turbidity occurred [64]. The cyanogenic glycoside was calculated as;

$$
\begin{gathered}
\text { Cyanogenic glycoside }(\mathrm{mg} / 100 \mathrm{~g})=\left(\text { Titrate value }\left(\mathrm{cm}^{3}\right) \times 1.08 \times\right. \text { exact } \\
\text { volume/Aliquot Volume } \left.\left(\mathrm{cm}^{3}\right) \times \text { sample weight }(\mathrm{g})\right) \times 100
\end{gathered}
$$

\subsubsection{Percentage Lipids}

Plant powder $(2.50 \mathrm{~g})$ was added to a soxhlet extractor and connected to a condenser. Petroleum ether was added, and lipids were extracted by heating at $50{ }^{\circ} \mathrm{C}$. Petroleum ether was removed, and the lipids were recovered by cooling in a desiccator, after which the flask was reweighted [64]. The lipid contents were calculated as;

$$
\% \text { Lipid }=(\text { Weight } \text { of Lipid } / \text { Weight of Sample }) \times 100
$$




\subsection{In Vitro Anticandida Activity}

4.4.1. Fungal Strains

C. albicans, C. glabrata, C. parapsilosis, C. krusei, C. tropicalis, and C. orthopsilosis were used.

\subsubsection{Inoculation}

A YPD Agar medium (Sigma-Aldrich (St. Louis, MO, United States) as prepared, and colonies of these strains were inoculated and allowed to grow over night at $37^{\circ} \mathrm{C}$. After that, they were stored at $4{ }^{\circ} \mathrm{C}$.

\subsubsection{Pre-Culture}

The YPD medium was prepared, placed in separate tubes, inoculated with a single colony of each fungal strain and incubated at $37^{\circ} \mathrm{C}$ in a shaker incubator Sigma-Aldrich (St. Louis, MO, United States).

\subsubsection{Microdilution Broth Protocol}

In a 96 well-plate $10 \mu \mathrm{L}$ of tested plant extract were taken. Ciprofloxacin was taken as a positive control and DMSO and water were taken as a blank control. Each well was then inoculated with $190 \mu \mathrm{L}$ inoculum (OD = 0.003 at $620 \mathrm{~nm}$ ). The plates were incubated at $37^{\circ} \mathrm{C}$ for $18 \mathrm{~h}$ and read on a Mithras LB 940 Multimode Microplate Reader Sigma-Aldrich (St. Louis, MO, United States) at $620 \mathrm{~nm}$.

\subsubsection{Small-Scale Extraction}

The fully desiccated raw plant material was ground into a fine powder and small-scale extractions were performed as described by Panda et al. [67]. One gram of plant powder was placed into four $15 \mathrm{~mL}$ sterile Falcon tubes each with a different solvent: acetone, hexane, ethanol, and water. The tubes were placed in a sonicator bath for $1 \mathrm{~h}$ after every $4 \mathrm{~h}$ interval. From each extract, $1 \mathrm{~mL}$ aliquots were dried in a Savant Speed Vac Concentrator $200 \mathrm{H}$. The dried filtrate was re-dissolved in $200 \mathrm{~mL}$ DMSO for the organic solvent extracts, and in $200 \mathrm{~mL}$ water for the aqueous extract. All samples were stored at $4{ }^{\circ} \mathrm{C}$ until further testing [67].

\subsubsection{Large-Scale Extraction}

For large scale extraction, the dried raw botanical material (200 $\mathrm{g}$ of powder) was transferred into a large container with $2000 \mathrm{~mL}$ of HPLC-grade $n$-hexane from Sigma-Aldrich (Hamburg, Germany). The container was left standing for $24 \mathrm{~h}$ at ambient temperature. During this time, the container was placed in a water bath sonicator 4 times for $60 \mathrm{~min}$ each to maximize the extraction yield. After each sonication, there was an interval of at least $6 \mathrm{~h}$ to let the suspension cool to ambient temperature. After the fourth sonication, the material was filtered using a VWR ${ }^{\circledR}$ Grade 313 with $5 \mu \mathrm{m}$ filter paper (from Sigma-Aldrich (Hamburg, Germany) to obtain a dry residue. The filtrate was then evaporated in a rotary evaporator (BUCHI rotavapor R-100, Sigma-Aldrich (St. Louis, MO 63118, United States) and the weight of the first dried extract was measured. The recovered hexane was again used for the second extraction using same procedure for $24 \mathrm{~h}$, after which the filtrate was again evaporated with a rotary evaporator to obtain dried extract. The same procedure was repeated to derive all the compounds from the plant powder. The final weight of the dried material was calculated and the plant extract was stored at $4{ }^{\circ} \mathrm{C}$ for further analysis.

The plant powder was dried again so it could be treated with a polar solvent to derive a polar compound with the same procedure.

\subsubsection{Fractionation Procedure}

The dried active extract was adsorbed onto silica gel (70-230 mesh) and loaded on a silica gel column (600 $\mathrm{mm}$ height $\times 55 \mathrm{~mm}$ diameter) Sigma-Aldrich (Hamburg, Germany) which was eluted (Waters Gradient Chromatography Calculator, model 600, Sigma-Aldrich (Hamburg, Germany) with a step gradient of hexane-dichloromethane that increased in 
polarity: $9.5: 0.5,9: 1,8.5: 0.5,8: 2,7: 3 ; 6: 4,5: 5,4: 6,3: 7,2: 8,1: 9$, and $0: 10$. The column was then eluted with $100 \%$ dichloromethane, and then $100 \%$ ethyl acetate, followed by a mixture of ethyl acetate and methanol (9.5:0.5, 9:1, 8:2, 7:3, 6:4, 5:5, 4:6, 3:7, 2:8, and 1:9). Finally, the column was eluted with $100 \%$ methanol. In each step, 10 tubes of $40 \mathrm{~mL}$ fractions were collected, and the solvent evaporated. The whole separation was monitored by a Dual $\lambda$ model 2487 absorbance detector (Waters Milford, MA, USA) at $280 \mathrm{~nm}$ and $254 \mathrm{~nm}$.

\subsubsection{Thin Layer Chromatography}

Aliquots $(5 \mu \mathrm{L})$ of the 245 fractions from the ethyl acetate extract were spotted on large TLC glass plates (Sigma-Aldrich, Hamburg Germany, dimensions $20 \mathrm{~cm} \times 20 \mathrm{~cm}$ ). The spotted plates were developed in glass jars $(20 \mathrm{~cm} \times 10 \mathrm{~cm} \times 20 \mathrm{~cm})$, pre-saturated with the chosen mobile phase at ambient temperature and dried in an oven (St. Louis, MO 63118, United States) at $90{ }^{\circ} \mathrm{C}$ for $5 \mathrm{~min}$ to remove the solvent. The plates were observed under ultra-violet (UV) light (Sigma-Aldrich, Hamburg Germany) at 254 and $360 \mathrm{~nm}$, followed by spraying with $5 \%$ sulfuric acid in ethanol, followed by heating at $100{ }^{\circ} \mathrm{C}$ for $5 \mathrm{~min}$. Fractions with similar TLC patterns were pooled for biological activity testing. In total, 22 pooled fractions were prepared and further tested for antimicrobial activity against $C$. albicans at a concentration of $1000 \mu \mathrm{g} / \mathrm{mL}$.

\subsubsection{HPLC-DAD Analysis}

HPLC analyses were performed on a Shimadzu, LC-20AT system (model DGU 20A3, SHIMADZU corporation, Kyoto, Japan) equipped with LC-20AT quaternary pump, a DGU20A3/DGU-20A5 on-line degasser, an SPD-20A photodiode array detector, and a CBM-20A/20A interface. The data were acquired and processed using Lab Solution software. The active fraction was analyzed using a reverse-phase HPLC column SHIMADZU corporation, Kyoto, Japan), SunfireTM prep C18 (10 mm $\times 250 \mathrm{~mm}, 5 \mu \mathrm{m})$ column (Waters, Ireland). The mobile phase was composed of $30 \% \mathrm{H}_{2} \mathrm{O}$ with $0.1 \%$ TFA (ACROS ORGANICS) and 70\% acetonitrile (LC-MS CHROMASOLVR, Fluka) with $0.1 \%$ TFA. Prior to HPLC injection, samples were filtered through a CHROMAFIL $\mathrm{R}$ Xtra H-PTFI filter (pore size $0.45 \mu \mathrm{m}$, filter $13 \mathrm{~mm}$, (MACHEREY-NAGEL, Düren, Germany). Two mL of sample was injected and run for $41 \mathrm{~min}$ at $20^{\circ} \mathrm{C}$ with a flow rate of $4 \mathrm{~mL} / \mathrm{min}$ [68].

\subsubsection{Mass Spectrometry GC-MS}

Collected peaks were analysed on a gas chromatograph (Thermo-Fisher Scientific Trace 1300 series, (Thermo Finnigan LLC, San Jose, CA, United States) coupled with a mass spectrometer (Thermo-Fisher Scientific ISQ series MS, Thermo Finnigan LLC, San Jose, CA, United States, The column used was a Restek RXi-5sil MS $20 \mathrm{~m}$ with an internal diameter of $0.18 \mathrm{~mm}$ and a film thickness of $0.18 \mu \mathrm{m}$. Helium was used as a carrier gas at a constant flow rate of $0.9 \mathrm{~mL} / \mathrm{min}$. The initial temperature of $40^{\circ} \mathrm{C}$ was held for $2 \mathrm{~min}$, then increased to $120{ }^{\circ} \mathrm{C}$ at a rate of $20{ }^{\circ} \mathrm{C} / \mathrm{min}$, to $200{ }^{\circ} \mathrm{C}$ at a rate of $10{ }^{\circ} \mathrm{C} / \mathrm{min}$, to $250{ }^{\circ} \mathrm{C}$ at a rate of $7^{\circ} \mathrm{C} / \mathrm{min}$, and finally to $350{ }^{\circ} \mathrm{C}$ at a rate of $5{ }^{\circ} \mathrm{C} / \mathrm{min}$, which was held for $4 \mathrm{~min}$. The spectrum corresponding to the largest peak in the chromatogram was searched against the NIST 14 MS library for identification. In addition, the identified compound was verified for its retention index, which was calculated using an external C7 to C40 alkane ladder.

\section{Conclusions}

In conclusion, the hexane extracts of B. bipinnata leaves showed anticandida activity due to the presence of linoleic acid and dehydroabietic acid. This supports the traditional use of Gui Zhen Cao. It is suggested that isolated compounds should be studied against different pure culture cell lines to identify their potential in vivo toxicity and also to understand their mode of action. In addition the activity of linoleic and dehydroabietic acids, with different combinations of compounds, must be studied to suggest possible synergistic effects. 
Author Contributions: Y.B. conceived of the idea. K.Z., M.I. and S.N. conducted the experiment and conducted the literature review. A.Q., W.A. and S.M. provided technical expertise. S.M., K.S. and Z.H.S. helped in statistical analysis. H.A., S.-H.Y. and G.C. proofread and provided intellectual guidance. All authors have read and agreed to the published version of the manuscript.

Funding: This work was carried out with the support of "Cooperative Research Program for Agriculture Science and Technology Development (Project No. PJ01581201)" Rural Development Administration, Republic of Korea.

Institutional Review Board Statement: Not applicable.

Informed Consent Statement: Not applicable.

Data Availability Statement: The data presented in this study are available upon fair request from the corresponding author.

Conflicts of Interest: The authors declare no conflict of interest.

Sample Availability: Not available.

\section{References}

1. Romano, B.; Lucariello, G.; Capasso, R. Topical Collection "Pharmacology of Medicinal Plants". Biomolecules 2021, 14, 101. [CrossRef]

2. Sharma, A.; Khanna, S.; Kaur, G.; Singh, I. Medicinal plants and their components for wound healing applications. Future J. Pharm. Sci. 2021, 7, 53. [CrossRef]

3. Hsu, H.; Chen, Y.; Hsu, C.; Shen, S.; Chen, C.; Chang, H. Oriental Materia Medica: A Concise Guide; Keats Publishing, Inc.: New Canaan, CT, USA, 1986.

4. Smith, F.; Stuart, G. Chinese Medicinal Herbs; Georgetown Press: San Francisco, CA, USA, 1973.

5. To-Ming, L.A. Analysis on a class of Banach algebras with applications to harmonic analysis on locally compact groups and semigroups. J. Math. Fundam. Sci. 1983, 118, 161-175. [CrossRef]

6. Bingshan, H.; Yuxia, W. Thousand Formulas and Thousand Herbs of Traditional Chinese Medicine; Heilongjiang Education Press: Harbin, China, 1993; Volume 1.

7. Pinto, E.D.P.P.; Amorozo, M.C.D.M.; Furlan, A. Conhecimento popular sobre plantas medicinais em comunidades rurais de mata atlântica-Itacaré, BA, Brasil. Acta Bot. Bras. 2006, 20, 751-762. [CrossRef]

8. Agra, M.D.F.; Silva, K.N.; Basílio, I.J.L.D.; Freitas, P.F.D.; Barbosa-Filho, J.M. Survey of medicinal plants used in the region Northeast of Brazil. Rev. Bras. Farmacogn. 2008, 18, 472-508. [CrossRef]

9. Feijó, E.V.R.S.; Pereira, A.S.; Souza, L.R.; Silva, L.A.M.; Costa, L.C.B. Levantamento preliminar sobre plantas medicinais utilizadas no bairro Salobrinho no município de Ilhéus, Bahia. Rev. Bras. Plantas Med. 2013, 15, 595-604. [CrossRef]

10. Sanoussi, F.; Ahissou, H.; Dansi, M.; Hounkonnou, B.; Agre, P.; Dansi, A. Ethnobotanical investigation of three traditional leafy vegetables [Alternanthera sessilis (L.) DC. Bidens pilosa L. Launaea taraxacifolia Willd.] widely consumed in southern and central Benin. J. Biodivers. Environ. Sci. 2015, 6, 187-198.

11. Chung, C.Y.; Yang, W.C.; Liang, C.L.; Liu, H.Y.; Lai, S.K.; Chang, C.L. Cytopiloyne, a polyacetylenic glucoside from Bidens pilosa, acts as a novel anticandidal agent via regulation of macrophages. J. Ethnopharmacol. 2016, 184, 72-80. [CrossRef]

12. Borges, C.C.; Matos, T.F.; Moreira, J.; Rossato, A.E.; Zanette, V.C.; Amaral, P.A. Bidens pilosa L. (Asteraceae): Traditional use in a community of southern Brazil. Rev. Bras. Plantas Med. 2013, 15, 34-40. [CrossRef]

13. Linhares, M.V.; da Silva, R.O.; de Oliveira, F.F.; Costa, L.C.B.; Conceição, A.O.; de Oliveira, R.A. Avaliation anti-Candida of essential oils from three medicinal plants species (Astereaceae). S. Afr. J. Bot. 2018, 115, 132-137. [CrossRef]

14. Oliveira, F.; Andrade-Neto, V.; Krettli, A.; Brandão, M. New evidences of antimalarial activity of Bidens pilosa roots extract correlated with polyacetylene and flavonoids. J. Ethnopharmacol. 2004, 93, 39-42. [CrossRef]

15. Ge, C. Cytologic study of Bidens bipinnata L. China J. Chin. Mater. Med. 1990, 15, 72-74.

16. Tan, P.V.; Dimo, T.; Dongo, E. Effects of methanol, cyclohexane and methylene chloride extracts of Bidens pilosa on various gastric ulcer models in rats. J. Ethnopharmacol. 2000, 73, 415-421. [CrossRef]

17. Kil, J.S.; Son, Y.; Cheong, Y.K.; Kim, N.H.; Jeong, H.J.; Kwon, J.W.; Pae, H.O. Okanin, a chalcone found in the genus Bidens, and 3-penten-2-one inhibit inducible nitric oxide synthase expression via heme oxygenase-1 induction in RAW264. 7 macrophages activated with lipopolysaccharide. J. Clin. Biochem. Nutr. 2012, 50, 53-58. [CrossRef]

18. Dimo, T.; Azay, J.; Tan, P.V. Effects of the aqueous and methylene chloride extracts of Bidens pilosa leaf on fructose-hypertensive rats. J. Ethnopharmacol. 2001, 76, 215-221. [CrossRef]

19. Surywanshi, V.; Yadava, R. Isolation and characterization of new potential allelochemical from Bidens biternata (Lour.) Merrill \& Sherff. J. Chem. Pharm. Res. 2015, 7, 175-179.

20. Geissberger, P.; Séquin, U. Constituents of Bidens pilosa L.: Do the components found so far explain the use of this plant in traditional medicine? Acta Trop. 1991, 48, 251-261. [CrossRef] 
21. Swapna, T.; Nair, A.; Mini, I.; Pradeesh, S. Free-radical scavenging activity of leaves of Bidens Biternata (Lour.) Merr. \& Sherif. J. Pharm. Res. Dev. 2014, 6, 127-135.

22. Kumari, P.; Misra, K.; Sisodia, B.S.; Faridi, U.; Srivastava, S.; Luqman, S.; Singh, S.C. A promising anticancer and antimalarial component from the leaves of Bidens pilosa. Planta Med. 2009, 75, 59. [CrossRef] [PubMed]

23. Sukumaran, P.; Nair, A.G.; Chinmayee, D.M.; Mini, I.; Sukumaran, S.T. Phytochemical investigation of Bidens biternata (Lour.) Merr. and Sheriff.-A nutrient-rich leafy vegetable from Western Ghats of India. Appl. Biochem. Biotechnol. 2012, 167, $1795-1801$. [CrossRef] [PubMed]

24. Kviecinski, M.R.; Felipe, K.B.; Schoenfelder, T.; de Lemos Wiese, L.P.; Rossi, M.H.; Gonçalez, E.; Pedrosa, R.C. Study of the antitumor potential of Bidens pilosa (Asteraceae) used in Brazilian olk medicine. J. Ethnopharmacol. 2008, 117, 69-75. [CrossRef] [PubMed]

25. Sharma, A.; Bargali, K.; Pande, N. The allelopathic potential of bryophyte extract on seed germination and seedling growth of Bidens biternata. Nat. Sci. 2009, 7, 30-38.

26. Ashafa, A.; Afolayan, A. Screening the root extracts from Biden pilosa L. var. radiata (Asteraceae) for antimicrobial potentials. J. Med. Plant. Res. 2009, 3, 568-572.

27. Zahara, K.; Bibi, Y.; Tabassum, S.; Bashir, T.; Haider, S.; Araa, A.; Ajmal, M. A review on pharmacological properties of Bidens biternata: A potential nutraceutical. Asian Pac. J. Trop. Dis. 2015, 5, 595-599. [CrossRef]

28. Chang, M.H.; Wang, G.J.; Kuo, Y.H.; Lee, C.K. The low polar constituents from Bidens pilosa L. var. minor (Van Sam, Baas, KEßLER, \& Plants) Sherff. J. Chin. Chem. Soc. 2000, 47, 1131-1136.

29. Zahara, K.; Bibi, Y.; Qayyum, A.; Nisa, S. Investigation of Antimicrobial and Antioxidant Properties of Bidens biternata. Iran. J. Sci. Technol. Trans. A Sci. 2019, 43, 725-734. [CrossRef]

30. Sarg, T.; Ateya, A.; Farrag, N.; Abbas, F. Constituents and biological activity of Bidens pilosa L. grown in Egypt. Acta Pharm. Hung. $1991,61,317-323$.

31. Wang, R.; Wu, Q.X.; Shi, Y.P. Polyacetylenes and flavonoids from the aerial parts of Bidens pilosa. Planta Med. 2010, 76, 893-896. [CrossRef]

32. Hoffmann, B.; Hölzl, J. Chalcone glucosides from Bidens pilosa. Phytochemistr 2009, 28, 247-249. [CrossRef]

33. Buhner, S.H. Herbal Antibiotics, Natural Alternatives for Treating Drug-Resistant Bacteria; Storey Publishing: North Adams, MA, USA; pp. 127-140.

34. Bseiso, E.A.; Nasr, M.; Sammour, O.; Gawad, N.A. Recent advances in topical formulation carriers of antifungal agents. Indian J. Dermatol. Venereol. Leprol. 2015, 8, 457-463. [CrossRef]

35. Arthur, G.D.; Naidoo, K.K.; Coopoosamy., R.M. Bidens pilosa L.: Agricultural and pharmaceutical importance. J. Med. Plant. Res. 2012, 6, 3282-3287. [CrossRef]

36. Borges, A.; José, H.; Homem, V.; Simões, M. Comparison of Techniques and Solvents on the Antimicrobial and Antioxidant Potential of Extracts from Acacia dealbata and Olea europaea. Antibiotics 2020, 9, 48. [CrossRef] [PubMed]

37. Dilika, F.; Bremner, P.D.; Meyer, J.J.M. Antibacterial activity of linoleic and oleic acids isolated from Helichrysum pedunculatum: A plant used during circumcision rites. Fitoterapia 2000, 71, 450-452. [CrossRef]

38. Freitas, H.R.; Isaac, A.R.; Malcher-Lopes, R.; Diaz, B.L.; Trevenzoli, I.H.; de Melo Reis, R.A. Polyunsaturated fatty acids and endocannabinoids in health and disease. Nutr. Neurosci. 2018, 21, 695-714. [CrossRef] [PubMed]

39. Kazemi, M. Chemical composition and antimicrobial, antioxidant activities and anti-inflammatory potential of Achillea millefolium L., Anethum graveolens L., and Carum copticum L. essential oils. J. Herb. Med. 2015, 5, 217-222. [CrossRef]

40. Hodaj, E.; Tsiftsoglou, O.; Abazi, S.; Hadjipavlou-Litina, D.; Lazari, D. Lignans and indole alkaloids from the seeds of Centaurea vlachorum Hartvig (Asteraceae), growing wild in Albania and their biological activity. Nat. Prod. Res. 2017, 31, 1195-1200. [CrossRef] [PubMed]

41. Kordali, S.; Cakir, A.; Akcin, T.A.; Mete, E.; Akcin, A.; Aydin, T.; Kilic, H. Antifungal and herbicidal properties of essential oils and n-hexane extracts of Achillea gypsicola Hub-Mor. and Achillea biebersteinii Afan. (Asteraceae). Ind. Crop. Prod. 2009, 29, 562-570. [CrossRef]

42. Deba, F.; Xuan, T.D.; Yasuda, M.; Tawata, S. Chemical composition and antioxidant, antibacterial and antifungal activities of the essential oils from Bidens pilosa Linn. var. Radiata. Food Control 2009, 19, 346-352. [CrossRef]

43. Wang, Y.-Q.; Li, S.J.; Man, Y.H.; Zhuang, G. Serum metabonomics coupled with HPLC-LTQ/orbitrap MS and multivariate data analysis on the ameliorative effects of Bidens bipinnata L. in hyperlipidemic rats. J. Ethnopharmacol. 2020, 262, 113196. [CrossRef]

44. Walters, D.; Raynor, L.; Mitchell, A.; Walker, R.; Walker, K. Antifungal activities of four fatty acids against plant pathogenic fungi. Mycopathologia 2004, 157, 87-90.

45. Greenway, D.L.A.; Dyke, K.G.H. Mechanism of the inhibitory action of linoleic acid on the growth of Staphylococcus aureus. Microbiology 1979, 115, 233-245. [CrossRef] [PubMed]

46. Jung, S.W.; Thamphiwatana, S.; Zhang, L.; Obonyo, M. Mechanism of antibacterial activity of liposomal linolenic acid against Helicobacter pylori. PLoS ONE 2015, 10, e0116519. [CrossRef] [PubMed]

47. Ghosal, S.; Singh, A.A.K.; Biswas, K.J.P.M. New 6-aryl-2-pyrones from Gentiana pedicellata. Planta Med. 1983, 49, $240-243$. [CrossRef] [PubMed]

48. Pereda-Miranda, R.; Hernández, L.; Villavicencio, M.J.; Novelo, M.; Ibarra, P.; Chai, H.; Pezzuto, J.M. Structure and stereochemistry of pectinolides AC, novel antimicrobial and cytotoxic 5, 6-dihydro- $\alpha$-pyrones from Hyptis pectinate. J. Nat. Prod. 1993, 56, 583-593. [CrossRef] 
49. Young, R.L.; Hylin, J.W.; Plucknett, D.L.; Kawano, Y.; Nakayama, R.T.J.P. Analysis for kawa pyrones in extracts of Piper methysticum. Phytochemistry 1996, 5, 795-798. [CrossRef]

50. Andrianaivoravelona, J.O.; Sahpaz, S.; Terreaux, C.; Hostettmann, K.; Stoeckli-Evans, H.; Rasolondramanitra, J. Two 6-substituted 5, 6-dihydro- $\alpha$-pyrones from Ravensara anisata. Phytochemistry 1999, 52, 265-269. [CrossRef]

51. Mpalantinos, M.A.; Soares de Moura, R.; Parente, J.P.; Kuster, R.M. Biologically active flavonoids and kava pyrones from the aqueous extract of Alpinia zerumbet. Phytother. Res. 1998, 12, 442-444.

52. Nachar, A.; Saleem, A.; Arnason, J.T.; Haddad, P.S. Regulation of liver cell glucose homeostasis by dehydroabietic acid, abietic acid and squalene isolated from balsam fir (Abies balsamea (L.) Mill.) a plant of the Eastern James Bay Cree traditional pharmacopeia. Phytochemistry 2015, 117, 373-379. [CrossRef]

53. Leandro, L.F.; Cardoso, M.J.O.; Silva, S.D.C.; Souza, M.G.M.; Veneziani, R.C.S.; Ambrosio, S.R.; Martins, C.H.G. Antibacterial activity of Pinus elliottii and its major compound, dehydroabietic acid, against multidrug-resistant strains. J. Med. Microbiol. 2014, 63, 1649-1653. [CrossRef]

54. Park, J.; Kim, W.J.; Kim, W.; Park, C.; Choi, C.Y.; Cho, J.H.; Cheong, H. Antihypertensive Effects of Dehydroabietic and 4-Epi-Trans-Communic Acid Isolated from Pinus densiflora. J. Med. Food 2021, 24, 50-58. [CrossRef]

55. Häkkinen, S.T.; Lackman, P.; Nygrén, H.; Oksman-Caldentey, K.M.; Maaheimo, H.; Rischer, H. Differential patterns of dehydroabietic acid biotrans, formation by Nicotiana tabacum and Catharanthus roseus cells. J. Biotechnol. 2012, 157, $287-294$. [CrossRef]

56. Gao, W.; Dong, X.; Xie, N.; Zhou, C.; Fan, Y.; Chen, G.; Zhu, D. Dehydroabietic acid isolated from Commiphora opobalsamum causes endothelium-dependent relaxation of pulmonary artery via PI3K/Akt-eNOS signaling pathway. Molecules 2014, 19, 8503-8517. [CrossRef]

57. Johnson, R.H.; Halitschke, R.; Kessler, A. Simultaneous analysis of tissue-and genotype-specific variation in Solidago altissima (Asteraceae) rhizome terpenoids, and the polyacetylene dehydromatricaria ester. Chemoecology 2010, 20, 255-264. [CrossRef]

58. Calou, I.B.F.; Sousa, D.I.M.; de Andrade Cunha, G.M.; de Castro Brito, G.A.; Silveira, E.R.; Rao, V.S.; Santos, F.A. Topically applied diterpenoids from Egletes viscosa (Asteraceae) attenuate the dermal inflammation in mouse ear induced by tetradecanoylphorbol 13-acetate-and oxazolone. Biol. Pharm. Bull. 2008, 31, 1511-1516. [CrossRef]

59. González, M.A. Aromatic abietane diterpenoids: Their biological activity and synthesis. Nat. Prod. Rep. 2015, 32, 684-704. [CrossRef] [PubMed]

60. Franich, R.A.; Gadgil, P.D.; Shain, L. Fungistatic effects of Pinus radiata needle epicuticular fatty and resin acids on Dothistroma pini. Physiol. Plant. Pathol. 1983, 23, 183-195. [CrossRef]

61. Savluchinske-Feio, S.; Nunes, L.; Pereira, P.T.; Silva, A.M.; Roseiro, J.C.; Gigante, B.; Curto, M.J.M. Activity of dehydroabietic acid derivatives against wood contaminant fungi. J. Microbiol. Methods 2007, 70, 465-470. [CrossRef] [PubMed]

62. Savluchinske-Feio, S.; Curto, M.J.M.; Gigante, B.; Roseiro, J.C. Antimicrobial activity of resin acid derivatives. Appl. Microbiol. Biotechnol. 2006, 72, 430-436. [CrossRef] [PubMed]

63. Tapia, A.A.; Vallejo, M.D.; Gouiric, S.C.; Feresin, G.E.; Rossomando, P.C.; Bustos, D.A. Hydroxylation of dehydroabietic acid by Fusarium species. Phytochemistry 1997, 46, 131-133. [CrossRef]

64. Ejikeme, C.; Ezeonu, C.S.; Eboatu, A.N. Determination of Physical and Phytochemical Constituents of some Tropical Timbers Indigenous to nigerdelta area of nigeria. Eur. Sci. J. 2014, 10, 247-270.

65. Okumu, M.O. Prophylactic Efficacy of Moringa Oleifera Leaf Extracts Against Liver Injury Induced by Artesunate-amodiaquine Antimalarial Combination. Ph.D. Thesis, University of Nairobi, Nairobi, Kenya, 2016.

66. Ezekaibeya, A.C.; Nnenna, A.O.; Kenechukwu, O.C. Proximate, phytochemical and vitamin compositions of Cucumis metuliferus (Horned Melon) rind. J. Complement. Altern. Med. Res. 2020, 9, 40-50. [CrossRef]

67. Panda, S.K.; Padhi, L.; Leyssen, P.; Liu, M.; Neyts, J.; Luyten, W. Antimicrobial, anthelmintic, and antiviral activity of plants traditionally used for treating infectious disease in the Similipal Biosphere Reserve, Odisha, India. Front. Pharmacol. 2017, 8, 658. [CrossRef] [PubMed]

68. Kerkoub, N.; Panda, S.K.; Yang, M.R.; Lu, J.G.; Jiang, Z.H.; Nasri, H.; Luyten, W. Bioassay-guided isolation of anti-Candida biofilm compounds from methanol extracts of the aerial parts of Salvia officinalis (Annaba, Algeria). Front. Pharmacol. 2018, 9, 1418. [CrossRef] [PubMed] 